\title{
Anterior and Posterior Iliac Crest Bone Graft Donor Site Morbidities: A Comparing Retrospective Study
}

\author{
Anterior ve Posterior İliak Kanat Kemik Grefti Donör Bölge Morbiditeleri: \\ Karșılaștırmalı Retrospektif Çalıșma
}

\author{
(D) Mehmet Ali Talmaç, (D) Mehmet Akif Görgel, (1) Muharrem Kanar, (1) Samet Erinç, (1) Ahmet Hamdi Olçar, (1) Hacı Mustafa Özdemir \\ Şişli Hamidiye Etfal Training and Research Hospital, Clinic of Orthopedic, İstanbul, Turkey
}

\section{ABSTRACT}

Objective: Autogenous bone grafts are frequently used in orthopedic surgery. The most common donor site for autogenous bone grafting is the iliac crest (IC). A number of complications have been reported after IC bone graft harvesting. The aim of this study was to compare anterior and posterior IC (AIC and PIC) harvesting site morbidities and postoperative subjective pain levels.

Methods: Eighty-seven patients were included in the study. Grafts were harvested from the posterior IC in 21 patients and from the AIC in 66 patients. We retrospectively reviewed all patients' preoperative demographics, types of graft obtained, scar dimensions ( $\mathrm{cm})$, and donor site complications. Pain level at harvesting site is evaluated with visual analog scale (VAS) score on a postoperative day l, 7, 2 weeks, 4 weeks, 8 weeks, and final follow-up.

Results: There was no statistically significant difference between the groups with respect to the preoperative demographics, types ratio of graft obtained, the mean follow-up time, complications ratio, and the mean VAS scores on 28, 56, and final follow-up. The mean VAS scores on 1, 7, and 14 in the ICA group were significantly higher than in the ICP group. The mean scar dimension of the ICP group was significantly higher than of the ICA group.

Conclusion: The AIC and PIC are optimal donor sites for harvesting. There was no difference in perioperative and postoperative complications between the AIC and PIC donor sites. Autologous bone grafting from the PIC decreased pain at the donor site compared to the AIC for at least two postoperative weeks. However, the PIC donor site had a poorer cosmetic appearance.

Keywords: Bone graft, complication, iliac crest, visual analogue scale

ÖZ

Amaç: Otojen kemik greftleri ortopedik cerrahide sıklıkla kullanılmaktadır. Otojen kemik grefti için en sık kullanılan verici bölge iliak kresttir (IC). IC kemik grefti alımından sonra birtakım komplikasyonlar bildirilmiştir. Bu çalışmanın amacı, anterior ve posterior IC (AIC ve PIC) donör bölge morbiditelerini ve postoperatif subjektif ağrı düzeylerini karşılaştırmaktır.

Yöntemler: Çalıșmaya 87 hasta dahil edildi. Greftler 21 hastada posterior IC ve 66 hastada AIC'den alındı. Tüm hastaların preoperatif demografik özellikleri, elde edilen greft tipleri, skar boyutları (cm) ve verici bölge komplikasyonları retrospektif olarak incelendi. Hasat bölgesindeki ağıı düzeyi, postoperatif 1. günde, 7. günde, 2. haftada, 4. haftada, 8. haftada ve son takipte visual analog skala (VAS) skoru ile değerlendirildi.

Bulgular: Gruplar arasında ameliyat öncesi demografik özellikler, elde edilen greft tipleri, ortalama takip süresi, komplikasyon oranları, postoperatif 4. hafta, 8. hafta ve son takip VAS skoru ortalamaları açııından istatistiksel olarak anlamlı fark yoktu. AIC grubunda postoperatif 1 . gün, 7. gün ve 2. hafta görsel analog skala skoru ortalamaları posterior IC grubundan istatistiksel olarak anlamlı derecede daha yüksekti. Posterior IC grubunun ortalama skar boyutu, AIC grubundan istatistiksel olarak anlamlı derecede yüksekti.

Sonuç: AIC ve PIC, graft almak için en uygun donör bölgelerdir. AIC ve PIC verici bölgeleri arasında perioperatif ve postoperatif komplikasyonlar açısından fark yoktu. Posterior IC'den otolog kemik greftlemesi, en az postoperatif iki hafta AIC'ye kıyasla verici bölgedeki ağrıyı azaltmış̦ır. Bununla birlikte, posterior IC verici alanı daha kötü bir kozmetik görünüme sahipti.

Anahtar Kelimeler: Kemik grafti, komplikasyon, iliak krest, visual analog skala

Received/Geliș tarihi: 24.10.2018 | Accepted/Kabul tarihi: 27.01.2019

Address for Correspondence/Yazıșma Adresi: Mehmet Ali Talmaç, Şișli Hamidiye Etfal Training and Research Hospital, Clinic of Orthopedic, İstanbul, Turkey

Phone/Telefon: +90 5555529329 E-mail/E-posta: drtalmac2@gmail.com ORCID-ID: orcid.org/0000-0001-7734-6438

Citation/Atıf: Talmaç MA, Görgel MA, Kanar M, Erinç S, Olçar AH, Özdemir HM. Anterior and Posterior Iliac Crest Bone Graft Donor Site Morbidities: A Comparing Retrospective Study. Bakırköy Tıp Dergisi 2019;15:244-9 https://10.4274/BTDMJB.galenos.2019.20181024012248 


\section{INTRODUCTION}

Autogenous bone grafts are frequently used in orthopedic surgery for reconstruction of bony defects, augment bone healing, lengthen bones, treating malunion or nonunion, spinal fusion surgery, or performing arthrodesis. In the United States, approximately 500.000 autogenous bone grafting procedures are performed annually (1).

The best origin of the bone graft is the autogenous bone, which has osteoinductive, osteoconductive, and osteogenic properties (2). The autogenous grafts are nonimmunogenic and it's more biological than allogenic grafts (3). Various donor sites such as iliac crest (IC), proximal tibia, distal radius, olecranon and rib can be used for autogenous bone grafts (3). The most common donor site for the autogenous bone grafting is the IC (4). IC donor sites have many advantages such as easy accessibility, the ability of primary wound healing, and having a large volume of bone (5-9). In addition, the harvesting of bone and preparation of the recipient site can be done simultaneously (7). There are also a number of disadvantages in terms of harvesting from IC. Due to the distance between IC internal and external cortices is very low especially at anterior iliac crest (AIC), harvesting can be difficult and fracture of IC may lead to other complications such as long-term immobilization $(8,9)$.

Autogenous bone graft volume at the IC donor site is enough for collecting of cancellous, cortical, or corticocancellous bone graft in the desired amount (5). However, a number of complications have been reported after AIC and posterior iliac crest (PIC) bone grafting. The reported complications were: prolonged pain, hematoma, seroma, infection, fracture, visceral complications, and paresthesia (6-10).

IC autogenous bone grafts can be harvested from AIC or PIC. The AIC is more accessible than the PIC but bone volume of PIC is greater than AIC $(2,8)$. Prefference the optimal approach for IC harvesting is a challenge for orthopedics surgeons. The aim of this study was to compare AIC and PIC bone grafting site morbidities and postoperative subjective pain levels. We wanted to define problems related to the donor sites of the IC.

\section{METHOD}

This study was conducted as a retrospective clinical study. The study protocol was approved by the Şişli Hamidiye Etfal
Hospital Ethics Committee. Ethics committee approval and number was 1270 . We identified 103 patients aged $\geq 18$ years who underwent bone graft surgery between September 2013 and September 2017. Indications in our study for bone graft surgery included reconstruction of bony defects, fracture malunion or nonunion, spinal fusion surgery and performing arthrodesis. We included patients whose bone grafts were harvested from AIC or PIC. Our exclusion criteria were age $<18$ years, history of bone graft surgery before September 2013, history of pelvis or proximal femur fracture before September 2013, cognitive impairment, paresthesia of the pelvic region or lower limbs, leg-length discrepancy, and a follow-up period of less than 1 year. Additionally, 3 patients were lost to follow-up. At finally, 87 patients were included in the study. Grafts were harvested from the PIC in 21 patients (ICP group) and from the AIC in 66 patients (ICA group).

Data for this study were collected from patient's history, the digital data bank including operated patients' informations and outpatient clinic notes. Demographic information was collected retrospectively following consent that included age, gender, body mass index (BMl; $\mathrm{kg} / \mathrm{m}^{2}$ ), smoking history, type of graft obtained from harvesting site (cancellous, bicortical, or cortico-cancellous), and scar dimension at harvesting site (cm). Subjective pain level at harvesting site is evaluated with visual analog scale (VAS) score on postoperative day 1 (PD 1), 7 (PD 7), 2 weeks (PD 14), 4 weeks (PD 28), 8 weeks (PD 56), and final follow-up. VAS scores were determined on a scale of 0 -10. Complications were divided into: iatrogenic bicortical perforation of the iliac crest; donor site seroma; donor site hematoma; donor site superficial or deep infection; pelvic fractur; impaired wound healing; arteriovenous fistula; disturbance of gait; paralytic ileus; ureteral injury; herniation; meralgia paraesthetica; tenderness during palpation; difficulties at walking and difficulties at climbing stairs. Statistical comparisons were made for all variables between the groups and the results were evaluated. Scar dimension, tenderness during palpation, difficulties at walking, and difficulties at climbing stairs were evaluated only at the final follow-up.

This study has been approved by Ethics Committee of our hospital. Informed consent was obtained from all patients included in the study. The study protocol was approved by the Șişli Hamidiye Etfal Hospital Ethics Committee. Ethics committee approval and number was 1270. 


\section{Statistical Analysis}

SPSS 15.0 for Windows 7 (IBM, Inc., Armonk, NY, USA) was used for the statistical analysis. Categorical variables are reported as numbers and percentages, while numerical variables are reported as means, standard deviations and minimum-maximum ranges. When the numerical variables provided the normal distribution condition, the independent two group comparisons were compared with Student's t-test, and when the normal distribution condition was not met, the Mann-Whitney $U$ test was compared with the chi-square analysis. For all tests, statistical significance was defined as an alpha level of $p<0.05$.

\section{RESULTS}

The mean age of 87 patients included in the study was $46.7 \pm 14.8$ (18-87) years, the mean BMI was $29.8 \pm 3.8$ (22.8$37.6)$, and 55 patients $(63.2 \%)$ were male. The mean follow- up time was $3.3 \pm 1.5$ (1-5) years. There was no statistically significant difference between the groups with respect to the mean age, male to female ratio, the mean BMI, smokers ratio, types ratio of graft obtained, the mean follow-up time, and complications ratio (Table 1) (Figure 1). The mean scar dimension was $7.4 \pm 0.8 \mathrm{~cm}$ in the ICP group and was statistically significant higher than in the ICA group $(4.5 \pm 0.8 \mathrm{~cm})$.

Complications not found in any patient were iatrogenic bicortical perforation of the IC, donor site deep infection, pelvic fractur, impaired wound healing, arteriovenous fistula, disturbance of gait, paralytic ileus, ureteral injury, herniation, and meralgia paraesthetica.

The mean VAS scores on PD 1, PD 7, and PD 14 in the ICA group were statistically significant higher than in the ICP group $(p<0.001)$ (Table 1). However, statistical analysis showed that there was no statistically significant difference

Table 1: Patients data

\begin{tabular}{|c|c|c|c|}
\hline Variable & ICA group ( $n=66)$ & ICP group ( $n=21)$ & $\mathbf{p}$ \\
\hline Age (years) & $46.4 \pm 14.9(18-87)$ & $47.6 \pm 15.0(18-84)$ & 0.747 \\
\hline Male gender & $41(62.1)$ & $14(66.7)$ & 0.707 \\
\hline BMI $\left(\mathrm{kg} / \mathrm{m}^{2}\right)$ & $29.7 \pm 3.6(23.5-36.8)$ & $30.2 \pm 4.4(22.8-37.6)$ & 0.691 \\
\hline Smoking history & $26(39.4)$ & $8(38.1)$ & 0.915 \\
\hline \multicolumn{4}{|l|}{ Type of graft obtained } \\
\hline Cortico-cancellous & 19 (28.8) & $8(38.1)$ & 0.553 \\
\hline Bicortical & $4(6.1)$ & $0(0.0)$ & \\
\hline Cancellous & $43(65.2)$ & $13(61.9)$ & \\
\hline Scar dimension (cm) & $4.5 \pm 0.8(2-5)$ & $7.4 \pm 0.8(6-8)$ & $<0.001$ \\
\hline Follow-up (years) & $3.3 \pm 1.5(1-5)$ & $3.1 \pm 1.5(1-5)$ & 0.578 \\
\hline \multicolumn{4}{|l|}{ VAS score at harvesting site } \\
\hline PD 1 & $5.32 \pm 0.71(4-6)$ & $3.24 \pm 0.54(2-4)$ & $<0.001$ \\
\hline PD 7 & $3.11 \pm 0.68(2-5)$ & $1.62 \pm 0.67(1-3)$ & $<0.001$ \\
\hline PD 14 & $2.23 \pm 0.55(1-3)$ & $0.71 \pm 0.46(0-1)$ & $<0.001$ \\
\hline PD 28 & $0.30 \pm 0.50(0-2)$ & $0.14 \pm 0.36(0-1)$ & 0.180 \\
\hline PD 56 & $0.11 \pm 0.31(0-1)$ & $0.00 \pm 0.00(0-0)$ & 0.122 \\
\hline Final follow-up & $0.00 \pm 0.00(0-0)$ & $0.00 \pm 0.00(0-0)$ & 1.000 \\
\hline \multicolumn{4}{|l|}{ Donor site complications } \\
\hline Seroma & $8(12.1)$ & $3(14.3)$ & 0.722 \\
\hline Hematoma & 7 (10.6) & $2(9.5)$ & 1.000 \\
\hline Superficial infection & $2(3.0)$ & $2(9.5)$ & 0.244 \\
\hline Tenderness during palpation & $5(7.6)$ & $1(4.8)$ & 1.000 \\
\hline Difficulties at walking & $14(21.2)$ & $2(9.5)$ & 0.337 \\
\hline Difficulties at climbing stairs & $16(24.2)$ & $3(14.3)$ & 0.545 \\
\hline
\end{tabular}




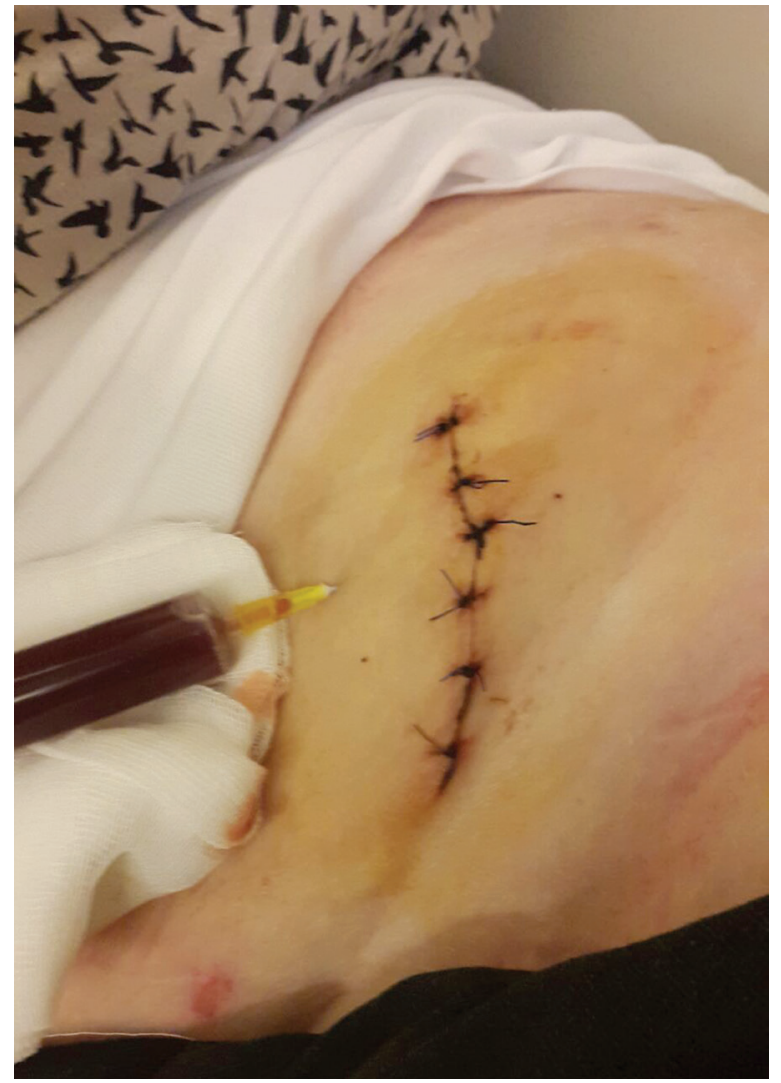

Figure 1: Postoperative AIC donor site minor complication AIC: Anterior iliac crest

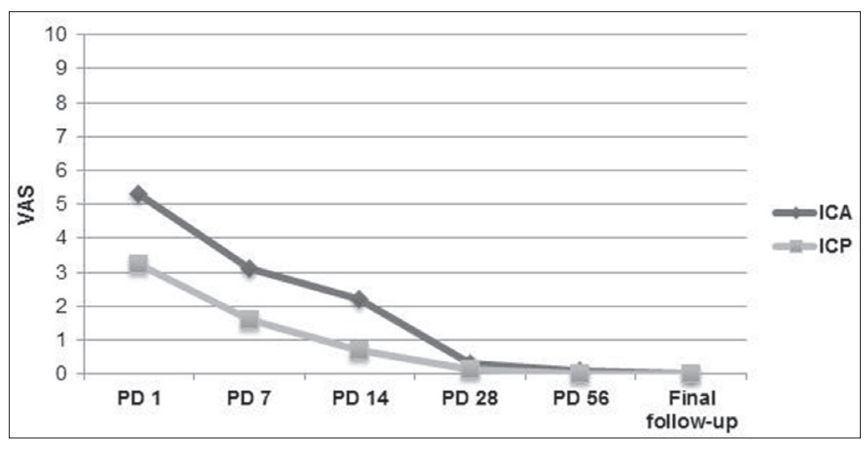

Figure 2: The mean VAS rating at the harvest site. The pain was statistically more severe in the ICA group than in the ICP group on PD 1, PD 7, and PD $14(p<0.001)$, with no significant difference in the mean VAS scores on PD 28, PD 56, and final follow-up

VAS: Visual analogue scale, ICA: Anterior iliac crest group, ICP: Posterior iliac crest group

between the groups in the aspect of the mean VAS scores on PD 28, PD 56, and final follow-up (Figure 2).

\section{DISCUSSION}

The most common donor site for autologous bone grafting is the IC. Determination of the donor site for harvesting depends on the required bone volume, patient's recipient site, and the surgeons' preference $(3,4)$. To avoid wasting extra time for bone harvesting procedure, orthopedic surgeons generally tends to select the donor site according to the patient's position on the operation table. Accordingly, if the spinal fusion with the posterior approach is planned, $\mathrm{PIC}$ is preferred for the donor site, however, AIC is preferred if the spinal fusion is planned with the anterior approach. Nevertheless, different harvesting sites have led to various complications associated with the donor sites (7-10). That the autologous bone grafting procedure is susceptible to occurring of various complications and morbidities necessitate the evaluating of the overall effectiveness of the procedures. Also, it is important to figure out different donor sites in terms of subjective pain, morbidity, quality, and quantity.

Hall et al. (1l) conducted a comparative anatomic cadaver study. They indicated that the mean cancellous bone volume of the PIC site statistically greater than the AIC site. In another comparative fresh cadaver study, Engelstad et al. (12) found that the mean compressed cancellous bone volume of the PIC site significantly greater than of the AIC site. Chiodo et al. (13) reported that osteogenic and hematopoietic progenitor cell content differences between the donor sites. However, Takemoto et al. (14) investigated the mRNA levels of bone morphogenetic proteins and their receptors in the bone marrow of the different donor sites and thay did not find any statistically significant differences between the three different donor sites. Marx et al. (15) reported that the yield of total nucleated, $\mathrm{CD} 44+$, and CD105+ cells was equal between the AIC and PIC. These results indicate that the qualitative choice more difficult than the quantitative choice between different donor sites.

IC donor site major complication rates described ranging from $2 \%$ to $8 \%$ in the literature and in a series of studies, major complications such as iatrogenic bicortical perforation of the iliac crest, donor site deep infection, pelvic fractur, impaired wound healing, and visceral complications have been reported perioperatively (710,16-21). However, none of the patients had any of these complications in our study. These results suggest that the harvesting can be collected from donor sites without major complication if surgical technical procedures are followed.

IC donor site minor complication rates described ranging from $9 \%$ to $40 \%$ in the literature $(7-10,17-21)$. A retrospective review showed that PIC donor site has the lower risk of 
minor complications than AIC donor site (7). Also, Edward and Michael (9) conducted a retrospective review that indicated the minor complication rate of PIC donor site was lower than the AIC donor site. However, Kessler et al. (8) reported that PIC and AIC donor site minor complication rates were similar. In our study, there was no statistically significant difference between the ICA and ICP groups for all complications.

Mauffrey et al. (22) found that the subjective pain from AIC donor site was higher than that at the proximal tibia or olecranon. In the literature, there was no study comparing the pain levels of AIC and PIC donor sites with VAS including postoperative two months and final follow-up. In the study of Ahlmann et al. (7), the variables related to pain were temporary pain and residual pain. They found that AIC donor site temporary and residual pain rates were $5 \%$ and $2 \%$, respectively. In addition, PIC donor site group patients did not have temporary or residual pain in their study. In our study, the mean VAS score of ICA group statistically significantly higher than the mean VAS score of ICP group, on PD 1, PD 5, and PD 14. However, as the patients recovered, no statistically significant differences the mean VAS scores of groups, on PD 28 and PD 56. All patients' VAS scores were 0 on final follow-up. These findings suggest that the PIC should be preferred for the patients allowed to mobilization and rehabilitation in the early postoperative period.

In the literature, smoking history is evaluated in a few studies related to autogenous bone grafting. Sheyan et al. reported that the tobacco using rate was $40 \%$ in the patients who underwent bone grafting from AIC (17). We found that the rate of tobacco using is similar to their study and no statistically significant differences between ICA and ICP groups were found. We also evaluated the types of obtained graft and we found no statistically significant difference between the groups.

IC donor site scar dimensions are important for cosmetic appearance. In the literature, including the morbidity of IC donor sites, the variables related to cosmetic appearance were generally subjective and there were no objective measurements $(7,19,21,23)$. The studies based on objective measurements of the scar dimensions did not compare the AIC and PIC donor sites scar dimensions, separately $(18,20,24)$. At the final follow-up, we measured the scar dimensions of all patients in $\mathrm{cm}$ and the mean scar dimension of ICP group was significantly higher than the ICA group. The reason for this result could be that the soft tissue thickness on the AIC donor site is less than the PIC donor site and this result implies that the ICP group patients have a poorer cosmetic appearance.

Despite our informative findings, this study had some limitations, including a retrospective study design, functional scale, the detailed consumption of analgesics, the bias of the patient's subjective tolerance to pain, and relatively small number of patients. In addition, there was no evaluation of graft quantity, of grafts' osteogenic, osteoinductive and osteoconductive effectiveness, of the VAS rating at the recipient site, and of bone union.

\section{CONCLUSION}

In conclusion, to summarize, the AIC and PIC are optimal donor sites for harvesting. There was no difference in perioperative and postoperative complications between the AIC and PIC donor sites. The patients in the ICP group have less pain than those in the ICA group at least two weeks postoperatively. However, the PIC donor site had a poorer cosmetic appearance.

\section{Ethics}

Ethics Committee Approval: The study protocol was approved by the Şişli Hamidiye Etfal Hospital Ethics Committee. Ethics committee approval and number was 1270.

Informed Consent: Informed consent was obtained from all patients included in the study.

Peer-Review: Externaaly and internally peer-review.

\section{Authorship Contributions}

Concept: M.A.T., M.A.G., H.M.Ö., Design: M.A.T., M.A.G., H.M.Ö., Data Collection or Processing: A.H.O., S.E., Analysis or Interpretation: M.K., Literature Search: A.H.O., S.E., Writing: M.A.T.

Conflict of Interest: No conflict of interest was declared by the authors.

Financial Disclosure: The authors declared that this study received no financial support.

\section{REFERENCES}

1. Greenwald AS, Boden SD, Goldberg VM, Khan Y, Laurencin CT, Rosier $\mathrm{RN}$, et al. Bone-graft substitutes: facts, fictions, and applications. J Bone Joint Surg Am 2001;83:98-103. 
2. Myeroff $C$, Archdeacon M. Autogenous bone graft: donor sites and techniques. J Bone Joint Surg Am 2011;93:27-36.

3. Huang YC, Chen CY, Lin KC, Renn JH, Tarng YW, Hsu CJ, et al. Comparing morbidities of bone graft harvesting from the anterior iliac crest and proximal tibia: a retrospective study. J Orthop Surg Res 2018;13:115-24.

4. Morris MT, Tarpada SP, Cho W. Bone graft materials for for posterolateral fusion made simple: a systematic review. Eur Spine J 2018;27:1856-67.

5. Kim DH, Rhim R, Li L, Martha J, Swaim BH, Banco RJ, et al. Prospective study of iliac crest bone graft harvest site pain and morbidity. Spine J 2009;9:886-92.

6. Goulet JA, Senunas LE, DeSilva GL, Greenfield ML. Autogenous iliac crest bone graft. Complications and functional assessment. Clin Orthop Relat Res1997;339:76-81.

7. Ahlmann E, Patzakis M, Roidis N, Shepherd L, Holtom P. Comparison of anterior and posterior iliac crest bone grafts in terms of harvestsite morbidity and functional outcomes. I Bone Joint Surg Am 2002;84:16-20.

8. Kessler P, Thorwarth M, Bloch-Birkholz A, Nkenke E, Neukam FW. Harvesting of bone from the iliac crest-comparison of the anterior and posterior sites. Br J Oral Maxillofac Surg 2005;6:43-51.

9. Edward MY, Michael WC. Morbidity at bone graft donor sites. J Orthop Trauma 1989;3:192-5

10. Becker ST, Warnke PH, Behrens E, Wiltfang J. Morbidity after iliac crest bone graft harvesting over an anterior versus posterior approach. J Oral Maxillofac Surg 2011;69:48-53.

11. Hall MB, Vallerand WP, Thompson D, Hartley G. Comparative anatomic study of anterior and posterior iliac crests as donor sites. J Oral Maxillofac Surg 1991;49:560-3.

12. Engelstad ME, Morse T. Anterior iliac crest, posterior iliac crest, and proximal tibia donor sites: a comparison of cancellous bone volumes in fresh cadavers. J Oral Maxillofac Surg 2010;68:3015-21.

13. Chiodo CP, Hahne J, Wilson MG, Glowacki J. Histological differences in iliac and tibial bone graft. Foot Ankle Int 2010;31:418-22.
14. Takemoto RC, Fajardo M, Kirsch T, Egol KA. Quantitative assessment of the bone morphogenetic protein expression from alternate bone graftharvesting sites. J Orthop Trauma 2010;24:564-6.

15. Marx RE, Tursun R. A qualitative and quantitative analysis of autologous human multipotent adult stem cells derivedfrom three anatomic areas by marrow aspiration: tibia, anterior ilium, and posterior ilium. Int J Oral Maxillofac Implants 2013;28:290-4.

16. Babbi L, Barbanti-Brodano G, Gasbarrini A, Boriani S. Iliac crest bone graft: a 23- years hystory of infection at donor site in vertebral arthrodesis and a review of current bone substitutes. Eur Rev Med Pharmacol Sci 2016;20:4670-6.

17. Armaghani SJ, Even JL, Zern EK, Braly BA, Kang JD, Devin CJ. The evaluation of donor site pain after harvest of tricortical anterior iliac crest bone graft for spinal surgery: A prospective study. Spine (Phila Pa 1976) 2016;41:191-6.

18. Sudhakar KNV, Mohanty R, Singh V. Evaluation of donor site morbidity associated with iliac crest bone harvest in oral and maxillofacial, reconstructive surgery. J Clin Diagn Res 2017;11:28-33.

19. Shin SR, Tormetta P 3rd. Donor site morbidity after anterior iliac bone graft harvesting. J Orthop Trauma 2016;30:340-3.

20. Kuik K, Putters TF, Schortinghuis J, van Minnen B, Vissink A, Raghoebar GM. Donor site morbidity of anterior iliac crest and calvarium bone grafts: A comparative case-control study. J Craniomaxillofac Surg 2016;44:364-8.

21. Loeffler BJ, Kellam JF, Sims SH, Bosse MJ. Prospective observational study of donor-site morbidity following anterior iliac crest bonegrafting in orthopaedic trauma trauma reconstruction patients. J Bone Joint Surg Am 2012;94:1649-54.

22. Mauffrey C, Madsen M, Bowles RJ, Seligson D. Bone graft harvest site options in orthopaedic trauma: a prospective in vivo quantification study. Injury 2012;43:323-6.

23. Gil-Albarova J, Gil-Albarova R. Donor site reconstruction in iliac crest tricortical bone graft: surgical technique. Injury 2012;43:953-6.

24. Fasolis M, Boffano P, Ramieri G. Morbidity associated with anterior iliac crest bone graft. Oral Surg Oral Med Oral Pathol Oral Radiol 2012;114:586-91. 